\title{
A role for pabAB, a p-aminobenzoate synthase gene of Streptomyces venezuelae ISP5230, in chloramphenicol biosynthesis
}

\author{
Michael P. Brown, Kwamena A. Aidoo and Leo C. Vining \\ Author for correspondence: Leo C. Vining. Tel: +1 902494 2040. Fax: +19024943736. \\ e-mail: lvining@ac.dal.ca
}

Department of Biology, Dalhousie University, Halifax, Nova Scotia, Canada B3H 4J1

\begin{abstract}
Mutagenesis of Streptomyces venezuelae ISP5230 and selection for paminobenzoic acid-dependent growth in the presence of sulfanilamide yielded pab mutants (VS519 and VS620) that continued to produce chloramphenicol $(\mathrm{Cm})$, although with increased medium dependence. Transforming the mutants with PDQ102 or PDQ103, which carried a pab-complementing fragment from $S$. venezuelae ISP5230 in alternative orientations, restored uniformly high $\mathrm{Cm}$ production in VS620, but did not alter the medium dependence of $\mathrm{Cm}$ production in VS519. The cloned S. venezuelae DNA fragment was subcloned and trimmed to the minimum size conferring pab complementation. The resulting $2.8 \mathrm{~kb}$ BamHI-Sacl fragment was sequenced. Codon preference analysis showed one complete ORF encoding a polypeptide of 670 amino acids. Comparison of the deduced amino acid sequence with database proteins indicated that the $\mathbf{N}$ - and C-terminal regions resembled PabA and PabB, respectively, of numerous bacteria. The gene product showed overall sequence similarity to the product of a fused pabAB gene associated with secondary metabolism in Streptomyces griseus. Insertion of an apramycin resistance gene into pabAB cloned in a segregationally unstable vector and replacement of the S. venezuelae chromosomal pabAB with the disrupted copy lowered sulfanilamide resistance from 25 to $5 \mu \mathrm{g} \mathrm{ml}^{-1}$ and blocked $\mathrm{Cm}$ production.
\end{abstract}

Keywords: Streptomyces venezuelae, $p$-aminobenzoate synthase gene, chloramphenicol

\section{INTRODUCTION}

$p$-Aminobenzoic acid (PABA) participates in primary metabolism as an intermediate in the formation of tetrahydrofolic acid. Its biosynthesis diverges from the pathway to aromatic protein amino acids through a branch-point reaction (Fig. 1) in which chorismic acid is channelled towards PABA formation by the successive actions of PABA synthase and 4-amino-4-deoxychorismic acid lyase (Nichols et al., 1989; Green \& Nichols, 1991). PABA synthase is a complex of two enzymes: an amidotransferase removes the amido group from glutamine and donates it to an aminase that substitutes it for the C-4 hydroxyl group of chorismic acid to form 4amino-4-deoxychorismic acid. The two enzymes are encoded by $p a b A$ and $p a b B$, respectively. The genes have

\footnotetext{
Abbreviations: Am, apramycin; $\mathrm{Cm}$, chloramphenicol; PABA, p-aminobenzoic acid; Ts, thiostrepton

The GenBank accession number for the pabAB nucleotide sequence reported in this paper is $\mathrm{U} 21728$.
}

been cloned and sequenced from a variety of organisms (Kaplan et al., 1985; Goncharoff \& Nichols, 1988; Tran et al., 1990; Slock et al., 1990; Arhin \& Vining, 1993). In enteric bacteria, they are at separate locations on the chromosome (Huang \& Pittard, 1967), whereas in Bacillus subtilis and Streptomyces lividans they are adjacent and are co-transcribed. The two genes in B. subtilis are clustered in an operon with other genes for folic acid biosynthesis (Slock et al., 1990). The conversion of 4-amino-4deoxychorismic acid to PABA is catalysed by a lyase, the gene for which $(p a b C)$ has now been identified and cloned (Green et al., 1992). In B. subtilis, a gene resembling $p a b C$ is present in the putative folic acid operon, but in Escherichia coli, $p a b C$, like $p a b A$ and $p a b B$, is individually located on the chromosome (Green \& Nichols, 1991).

In addition to its role in primary metabolism, PABA serves as a secondary metabolic pathway intermediate in Streptomyces griseus, where it appears to form the starter unit for the biosynthesis of the polyketide-derived antibiotic candicidin (Gil et al., 1980). In Streptomyces venezuelae, the secondary metabolic pathway to the antibiotic 


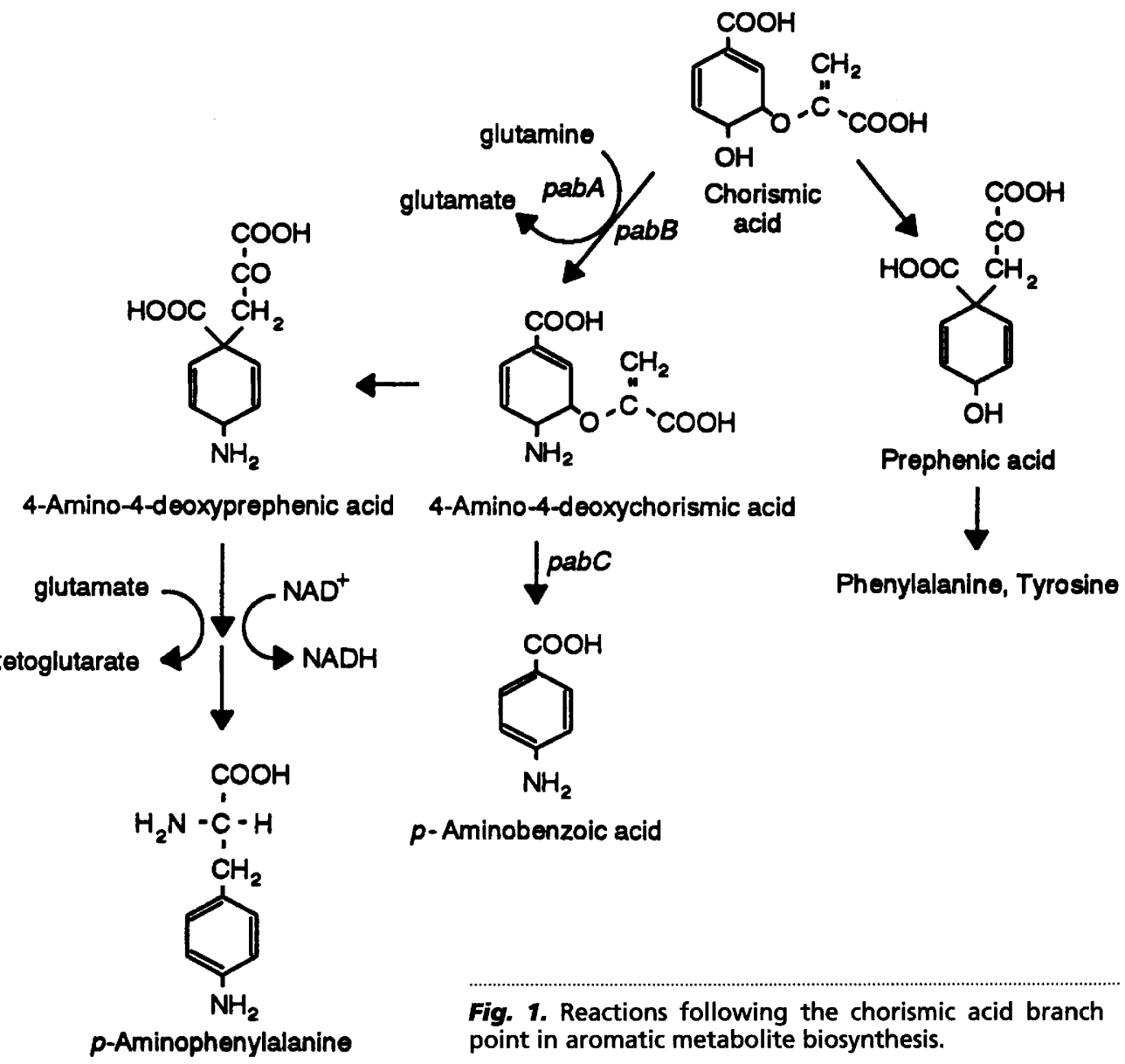

Fig. 1. Reactions following the chorismic acid branch point in aromatic metabolite biosynthesis.

chloramphenicol $(\mathrm{Cm})$ also branches from the route to aromatic protein amino acids at chorismic acid (see Fig. 1; Vining \& Stuttard, 1994). Teng et al. (1985) established that $p$-aminophenylalanine, an intermediate in $\mathrm{Cm}$ biosynthesis, is derived from chorismic acid via 4-amino-4deoxychorismic acid and thus shares this initial step with the biosynthesis of PABA. In the route to $p$-aminophenylalanine, the lyase reaction that would otherwise form PABA is replaced with a mutase that generates 4amino-4-deoxyprephenic acid; this intermediate may be converted to $p$-aminophenylalanine via $p$-aminophenylpyruvic acid (Jones et al., 1978), although detection of both arogenate dehydrogenase and prephenate dehydratase in $S$. venezuelae (Lingens \& Keller, 1983) suggests that an alternative reaction sequence via the arogenic acid intermediate should not be excluded. The dual role of 4 amino-4-deoxychorismic acid as an intermediate in both PABA and $\mathrm{Cm}$ biosynthesis suggests that it represents a branch point for primary and secondary metabolism and raises questions about the regulation of the branching reactions, as well as about the evolution of the secondary pathway.

Aidoo (1989) isolated a putative PABA synthase gene from a Cm-producing organism by cloning in the Streptomyces vector pIJ41 a fragment of $S$. venezuelae ISP5230 DNA complementing a pab mutation in $S$. lividans (Gil \& Hopwood, 1983). This pab-containing
DNA has now been subcloned in an $E$. coli vector as a $2.8 \mathrm{~kb}$ fragment and sequenced, revealing features of PABA synthase that bear on its relationship to primary and secondary metabolism in $S$. venezuelae. The chromosomal gene in $S$. venezuelae has been disrupted to determine whether it has a role in $\mathrm{Cm}$ production.

\section{METHODS}

Bacteria, plasmids and cultures. The micro-organisms and plasmids used are described in Table 1. Streptomyces venezuelae strains were maintained on MYM agar (Stuttard, 1982); $S$. lividans JG10 was maintained on $\mathrm{K} 1$ medium, which contained $\left(\mathrm{l}^{-1}\right)$ : maltose $(10 \mathrm{~g})$, yeast extract ( $5 \mathrm{~g}$, Difco), Casamino acids $\left(0.2 \mathrm{~g}\right.$, Difco), $\mathrm{K}_{2} \mathrm{HPO}_{4}(0.5 \mathrm{~g}), \mathrm{MgSO}_{4} .7 \mathrm{H}_{2} \mathrm{O}(0.2 \mathrm{~g})$, $\mathrm{FeSO}_{4} \cdot 7 \mathrm{H}_{2} \mathrm{O}(0 \cdot 1 \mathrm{~g})$ and agar $(15 \mathrm{~g})$. Cultures of $S$. venezuelae and $S$. lividans were grown as described by Aidoo et al. (1990). Spores of $S$. venequelae ISP5230 were mutagenized with NTG in Tris/maleate buffer, $\mathrm{pH} 8 \cdot 0$, as described by Delić et al. (1970). Mutants defective in PABA biosynthesis were selected by plating the spores on minimal medium (MM) supplemented with PABA $\left(1.0 \mu \mathrm{g} \mathrm{ml}^{-1}\right)$ and then screened by replica plating on $\mathrm{MM}$ containing sulfanilamide $\left(10 \mu \mathrm{g} \mathrm{ml}^{-1}\right)$. The sensitivity level of colonies that failed to grow in the presence of sulfanilamide was tested by incubating spores on MM agar supplemented with sulfanilamide at various concentrations; reversal of the inhibition by PABA was tested by incubating spores on MM agar containing sulfanilamide and PABA at 10 and $1.0 \mu \mathrm{g} \mathrm{ml}^{-1}$, respectively. MM consisted of a glucose/asparagine/salts solution (Hopwood, 1967); unwashed agar (Difco) was used in 
Table 1. Bacterial strains and plasmids used

\begin{tabular}{|c|c|c|}
\hline Strain & Genotype/phenotype & Source/reference \\
\hline \multicolumn{3}{|l|}{ S. venezuelae } \\
\hline ISP5230 & Wild-type & Stuttard (1982) \\
\hline VS519 & Sulfanilamide-sensitive mutant $(p a b-2,3)$ of ISP5230 & Atkinson (1987) \\
\hline VS620 & Sulfanilamide-sensitive mutants ( $p a b-10 p a b-11)$ of ISP5230 & This work \\
\hline VS629 & Wild-type transformed with pDQ501 & This work \\
\hline \multicolumn{3}{|l|}{ S. lividans } \\
\hline JG10 & pab-1 str-6 SLP2- SLP3- & Gil \& Hopwood (1983) \\
\hline \multicolumn{3}{|l|}{ E. coli } \\
\hline TG1 & supE bsd $\Delta($ lac-pro $A B) F^{\prime}\left(\right.$ traD36 pro $A B^{+}$lac $I^{q}$ lac $\left.Z \Delta \mathrm{M} 5\right)$ & Carter et al. (1985) \\
\hline $\mathrm{DH} 5 \alpha \mathrm{F}^{\prime} \mathrm{IQ}$ & $\begin{array}{l}\mathrm{F}^{\prime} \phi 80 \mathrm{~d} l a c Z \Delta \mathrm{M} 15 \Delta(\operatorname{lac} Z Y A-\arg F) \mathrm{W} 169 \operatorname{deoR} \operatorname{rec} A 1 \text { bsd } 17 \\
\left(\mathrm{t}_{\mathrm{k}}^{-} \mathrm{m}_{\mathrm{k}}^{+}\right) \operatorname{supE44} \text { thi-1 gyr } A 96 \operatorname{rel} A 1 \mathrm{~F}^{\prime} \text { pro } A B^{+} \text {lac }{ }^{\mathrm{q}} Z \Delta \mathrm{M} 15 \\
2 Z f: \operatorname{Tn} 5\left[\mathrm{Km}^{\mathrm{r}}\right]\end{array}$ & Hanahan (1983) \\
\hline ET12567 & dam $d c m$ bsdM & MacNeil et al. (1992) \\
\hline \multicolumn{3}{|l|}{ Plasmids } \\
\hline pBluescript II & E. coli phagemid vector: $\mathrm{Ap}^{\mathrm{R}}$ lac $Z^{\prime}$ & Stratagene \\
\hline $\mathrm{pTZ18R} / 19 \mathrm{R}$ & E. coli phagemid vector: $\mathrm{Ap}^{\mathrm{R}}$ lac $Z^{\prime}$ & Pharmacia \\
\hline pIJ41 & Modified S. lividans plasmid SLP1.2: $\mathrm{Neo}^{\mathrm{R}} \mathrm{Ts}^{\mathrm{R}}$ & Chater et al. (1982) \\
\hline $\mathrm{pHJL} 400$ & E. coli-Streptomyces bifunctional vector: $\operatorname{Par}^{-} A p^{R} T s^{R}$ & Larson \& Hershberger (1986) \\
\hline pDQ101 & Modified pIJ941 (transforms S. venequelae) & Aidoo et al. (1990) \\
\hline pDQ102/103 & $\begin{array}{l}\text { pDQ101 with a } 6.4 \mathrm{~kb} P s t \mathrm{I} \text { insert from } \mathrm{pDQ} 116 \text { (two } \\
\text { orientations) }\end{array}$ & Aidoo et al. (1990) \\
\hline pDQ116 & pIJ41 with a $5.65 \mathrm{~kb} S$. venezuelae insert containing pab $A B$ & This work \\
\hline pDQ121 & pIJ41 with a $3.4 \mathrm{~kb} S$. venequelae insert containing $p a b A B$ & This work \\
\hline pDQ372 & pHJL400 with a $6.4 \mathrm{~kb}$ PstI insert from pDQ116 & This work \\
\hline pDQ373 & pDQ372 lacking the $2.7 \mathrm{~kb} B a m \mathrm{HI}-$ Bam HI segment & This work \\
\hline pDQ500 & $\begin{array}{l}\text { pDQ373 lacking } 1.4 \mathrm{~kb} X b o \mathrm{I}-X h o \mathrm{I} \text { and } 0.21 \mathrm{~kb} \text { NcoI-NcoI } \\
\text { segments }\end{array}$ & This work \\
\hline pDQ501 & pDQ500 with an apr insert & This work \\
\hline $\mathrm{pKC} 462 \mathrm{a}$ & Cosmid vector containing $a p r$ & Stanzak et al. (1986) \\
\hline
\end{tabular}

determining requirements for $\mathrm{PABA}$ and sensitivity to sulfanilamide.

DNA manipulations. The general procedures described by Sambrook et al. (1989) were followed. Plasmid DNA was isolated from streptomycetes by the alkaline lysis method of Kieser (1984). Genomic DNA was obtained as described by Hopwood et al. (1985). For Southern hybridizations (Southern, 1975), DNA probes were labelled with $\left[\alpha_{-}{ }^{32} \mathrm{P}\right] \mathrm{dCTP}$ by the random priming procedure. Hybridization was carried out at $65^{\circ} \mathrm{C}$ in a solution containing $5 \times$ SSPE (SSPE is $0.18 \mathrm{M} \mathrm{NaCl}$, $10 \mathrm{mM} \mathrm{Na}_{2} \mathrm{HPO}_{4}$ and $1 \mathrm{mM}$ EDTA, pH 7.7), $5 \times$ Denhardt's solution (Denhardt, 1966), 0.5\% SDS and denatured salmon sperm DNA $\left(100 \mu \mathrm{g} \mathrm{ml}^{-1}\right)$. Membranes were washed at $65^{\circ} \mathrm{C}$ with SSPE solutions (twice with $2 \times$, then with $1 \times$ and $0.1 \times$ ) containing $0 \cdot 1 \%$ SDS.

Cloning and transformation. Competent cells of E. coli strains were prepared and transformed as described by Sambrook $e t$ al. (1989). To prepare genomic libraries of $S$. venezuelae DNA, wildtype strain ISP5230 DNA was digested to completion with either $B c I$ or $B a m H I$ and a $5 \mu \mathrm{g}$ sample was ligated to $1 \mu \mathrm{g}$ of pIJ41 (Chater et al., 1982) linearized with BamHI. Each of the ligation mixtures was used to transform the sulfanilamidesensitive $S$. lividans mutant JG10, using the general procedures of Hopwood et al. (1985). Incubating excess S. lividans JG10 protoplasts with the ligation mixture containing $B c l$ fragments yielded $1.2 \times 10^{4}$ transformants, in $20 \%$ of which the vector contained an insert; the ligation mixture containing Bam $\mathrm{HI}$ fragments yielded $5 \times 10^{3}$ transformants. Thiostrepton(Ts)resistant colonies were replica-plated on $\mathrm{MM}$ agar supplemented with $0 \cdot 2 \mu \mathrm{g}$ sulfanilamide $\mathrm{ml}^{-1}$. At this concentration, the drug selected for transformants carrying a pab gene that complemented the host mutation and allowed growth similar to that of the wild-type. For transforming $S$, venezuelae, the procedures described by Aidoo et al. (1990) were used.

DNA sequencing and sequence analysis. DNA fragments were subcloned in both orientations in pBluescript II SK $(+)$ and overlapping deletions were generated with exonuclease III (Henikoff, 1984). The ligated DNA was used to transform $E$. coli $\mathrm{DH} 5 \alpha \mathrm{F}^{\prime} \mathrm{IQ}(\mathrm{BRL})$ and plasmid DNA, extracted from the transformants by the rapid boiling method (Holmes \& Quigley, 1981), was screened for size by agarose gel electrophoresis. Single-strand DNA templates were generated from phagemid inserts by incubating cultures with helper phage VCSM13 as described by Karger \& Jessee (1990), except that the culture medium contained yeast extract $(1.0 \%)$, Bacto-Tryptone $(1.6 \%$, $\mathrm{w} / \mathrm{v})$ and $\mathrm{NaCl}(0.8 \%)$. The single strands were sequenced by the dideoxy chain-termination method (Sanger et al., 1977) using Sequenase version 2.0 (Amersham) and $\left[\alpha^{-35} \mathrm{~S}\right] \mathrm{dATP}$. The sequence was analysed with version 7.0 software developed by the Genetics Computer Group (GCG), University of Wisconsin, Madison, WI, USA.

Construction and use of a pabAB replacement vector. pDQ373 (see Table 1) was digested with $X b o I$ to remove a $1.4 \mathrm{~kb}$ segment of DNA from the vector fragment, which was 
then circularized with T4 DNA ligase. The resulting plasmid was digested with $N c o I$ to remove a $0.21 \mathrm{~kb}$ segment of DNA and again circularized by incubation with T4 DNA ligase. This plasmid was linearized with $N c o I$ and ligated with an $N c o I$ cassette carrying the apramycin (Am) resistance gene (apr) subcloned from pKC462a (Stanzak et al., 1986; Paradkar \& Jensen, 1995). The ligation mixture was used to transform $E$. coli $\mathrm{TG} 1$; from a transformant exhibiting the $\mathrm{Am}^{\mathrm{R}}$ phenotype, plasmid pDQ501 was isolated. This was used to transform $E$. coli ET12567 (MacNeil et al., 1992); pDQ501 reisolated from this host was used as the replacement vector. Protoplasts of $S$. venezuelae ISP5230 were transformed with $\mathrm{pDQ} 501$ by the procedure of Aidoo et al. (1990). One colony from about 80 that grew on the protoplast regeneration medium containing Ts $\left(20 \mu \mathrm{g} \mathrm{ml}^{-1}\right)$ was confirmed to be resistant to both Am (50 $\mu \mathrm{g}$ $\mathrm{ml}^{-1}$ ) and Ts. It was then transferred to MYM agar and allowed to sporulate. Replica plating on MYM agar containing Am or Ts identified colonies with an $\mathrm{Am}^{\mathrm{R}} \mathrm{Ts}^{\mathrm{s}}$ phenotype. Genomic DNA was isolated from these strains, digested with $S a c I$ and examined by Southern hybridization using the $1.8 \mathrm{~kb}$ SacI-SacI fragment from pDQ373 and the $1.45 \mathrm{~kb}$ apr cassette as probes.

Measurement of $\mathrm{Cm}$ production. $\mathrm{Cm}$ production by $S$. venezuelae strains grown as patches on MYM agar was bioassayed against Micrococcus luteus as described by Aidoo et al. (1990). To measure $\mathrm{Cm}$ production in liquid medium, $25 \mathrm{ml}$ cultures were incubated in $250 \mathrm{ml}$ Erlenmeyer flasks on a rotary shaker (220 r.p.m.) at $27^{\circ} \mathrm{C}$. The glucose/isoleucine medium (Doull $e t$ al., 1985) was inoculated $(2 \% \mathrm{v} / \mathrm{v})$ from a vegetative culture prepared by incubating $S$. venezuelae spores for $24 \mathrm{~h}$ in $10 \mathrm{ml}$ GNY medium (Malik \& Vining, 1970). Cm in production cultures grown for 2, 4 and $6 \mathrm{~d}$ was extracted from $3 \mathrm{ml}$ samples of the clarified broth with an equal volume of ethyl acetate. The extract was evaporated until dry, taken up in $0.1 \mathrm{ml}$ methanol/ water $(3: 1, \mathrm{v} / \mathrm{v})$ and analysed $(20 \mu$ injection) by HPLC using a $\mathrm{C}_{18}$ reverse phase column $(80 \times 4.0 \mathrm{~mm})$ and stepped linear gradients from 0 to $25 \%$ ( $1 \mathrm{~min}$ ), 25 to $50 \%$ ( $5 \mathrm{~min}$ ) and 50 to $100 \%(1 \mathrm{~min})$ methanol in water $(\mathrm{v} / \mathrm{v})$, followed by $100 \%$ methanol for $1 \mathrm{~min}$ and a gradient returning to $100 \%$ water $(1 \mathrm{~min}) . \mathrm{Cm}$ was eluted at $6.05 \mathrm{~min}$; its concentration was estimated by comparing the peak area with peak areas given by reference samples.

\section{RESULTS}

\section{Sensitivity of S. lividans and S. venezuelae strains to sulfanilamide}

Strains of $S$. lividans that had no growth requirement for PABA were sensitive to sulfanilamide at concentrations above $2 \mu \mathrm{g} \mathrm{m}^{-1}$. The pab mutation in S. lividans JG10 (Gil \& Hopwood, 1983) markedly increased the sensitivity; growth of this strain was completely inhibited at $0.2 \mu \mathrm{g}$ $\mathrm{ml}^{-1}$. Wild-type $S$. venezuelae ISP5230 was appreciably less sensitive to sulfanilamide and could grow at concentrations up to $25 \mu \mathrm{g} \mathrm{ml} \mathrm{m}^{-1}$. A pab mutant (VS519; Atkinson, 1987) isolated after treatment of the wild-type with NTG was inhibited by $2 \mu \mathrm{g}$ sulfanilamide $\mathrm{ml}^{-1}$. To isolate additional pab mutants, mutagenized spores of $S$. venezuelae ISP5230 were screened on MM agar containing $10 \mu \mathrm{g}$ sulfanilamide $\mathrm{ml}^{-1}$. At this inhibitor concentration, $0.2 \%$ of the survivors were unable to grow. Two of those inhibited (designated VS620) were examined; each showed marginal growth with $5 \mu \mathrm{g}$ sulfanilamide $\mathrm{ml}^{-1}$ and grew normally when additionally supplemented with PABA.

\section{$\mathrm{Cm}$ production by $\mathrm{S}$. venezuelae pab mutants}

Atkinson (1987) was unable to detect antibiotic production by the pab mutant strain VS519 in bioassays on MYM agar, although positive bioassays were obtained when this strain was patched on a defined agar medium favouring production of the antibiotic. On MYM agar both VS620 strains gave positive bioassays for $\mathrm{Cm}$, but the titres were lower than for the wild-type. In shaken cultures grown in the glucose/isoleucine medium optimized for Cm production (Chatterjee et al., 1983; Doull et al., 1985), HPLC analyses showed wild-type titres of the antibiotic in all of the mutant strains. The anomalous results from bioassays of cultures grown on agar media were attributed to growth rate effects (Liao et al., 1995) and were not investigated further.

\section{Cloning of the $p$-aminobenzoate synthase gene}

By restriction enzyme mapping of plasmid DNA extracted from sulfanilamide-resistant $S$. lividans transformants, the same $5.65 \mathrm{~kb}$ segment (e.g. the insert in pDQ116; Fig. 2a) was identified within four of the $B c l$ inserts of $S$. venezuelae DNA. Since the same insert was present in two of the recombinant $\mathrm{pIJ} 41$ vectors in alternative orientations, complementation of the host phenotype by both plasmids suggested that the fragment included a promoter for the $p a b$ gene. A restriction map of the $3.4 \mathrm{~kb}$ insert in pDQ121, the plasmid extracted from the single sulfanilamide-resistant transformant derived from the Bam $\mathrm{HI}$ fragments of $S$. venezuelae genomic DNA, indicated that this fragment formed part of the $5.65 \mathrm{~kb}$ region common to the $B c$ II-derived inserts (see Fig. 2a).

To determine whether the gene was expressed in E. coli, a $6.4 \mathrm{~kb}$ fragment containing most of the $5.65 \mathrm{~kb}$ insert and an additional $0.75 \mathrm{~kb}$ of adjacent vector DNA (see Fig. 2a) was excised with Pst $\mathrm{I}$ from $\mathrm{pDQ} 116$ and ligated into the Pst I site of the E. coli vector pTZ18R (Mead \& Kemper, 1988). Incubating E. coli TG1 with the pTZ18R ligation mixture gave transformants from which plasmids containing the insert in alternative orientations were isolated. When these were used to transform $E$. coli mutants AB3292 and AB3295, defective in $p a b A$ and $p a b B$, respectively, none of the 500 transformants tested was prototrophic, implying that the promoter region of the cloned S. venezuelae gene(s) did not function in E. coli.

\section{Transformation of S. venezuelae pab mutants}

Aidoo et al. (1990) recloned the $6.4 \mathrm{~kb}$ Pst $\mathrm{I}-$ Pst $\mathrm{I}$ insert from $\mathrm{pDQ} 116$ in the $S$. venequelae-compatible vector pDQ101 to give pDQ102 and pDQ103 (alternative orientations). Both plasmids complemented the pab mutation when introduced into $S$. lividans JG10, but did not restore $\mathrm{Cm}$ production in an $S$. venezuelae mutant blocked at an early step in biosynthesis of the antibiotic (Aidoo $e t$ al., 1990). Transformation of the $S$. venezuelae pab mutants VS519 and VS620 with pDQ102 yielded Ts-resistant colonies at the same frequency as transformations of the wild-type. All of the eight colonies examined from the VS620 transformation showed resistance to sulfanilamide and produced $\mathrm{Cm}$ at wild-type levels (as determined by 


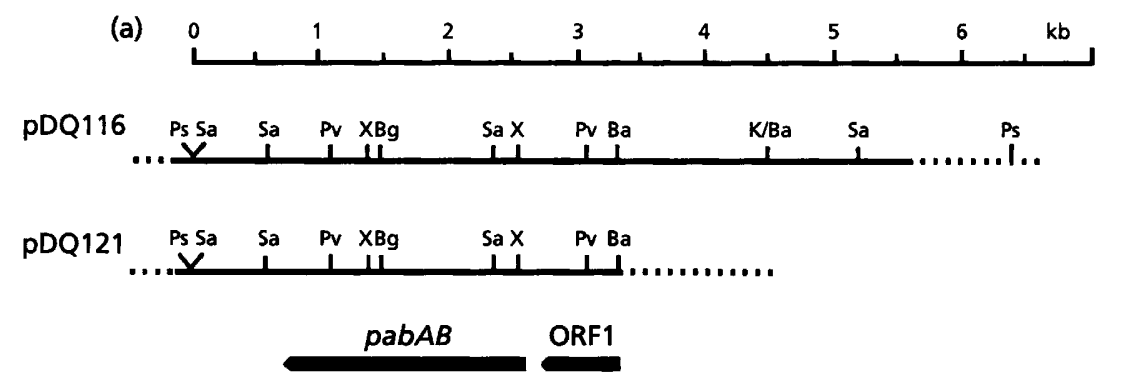

(b)

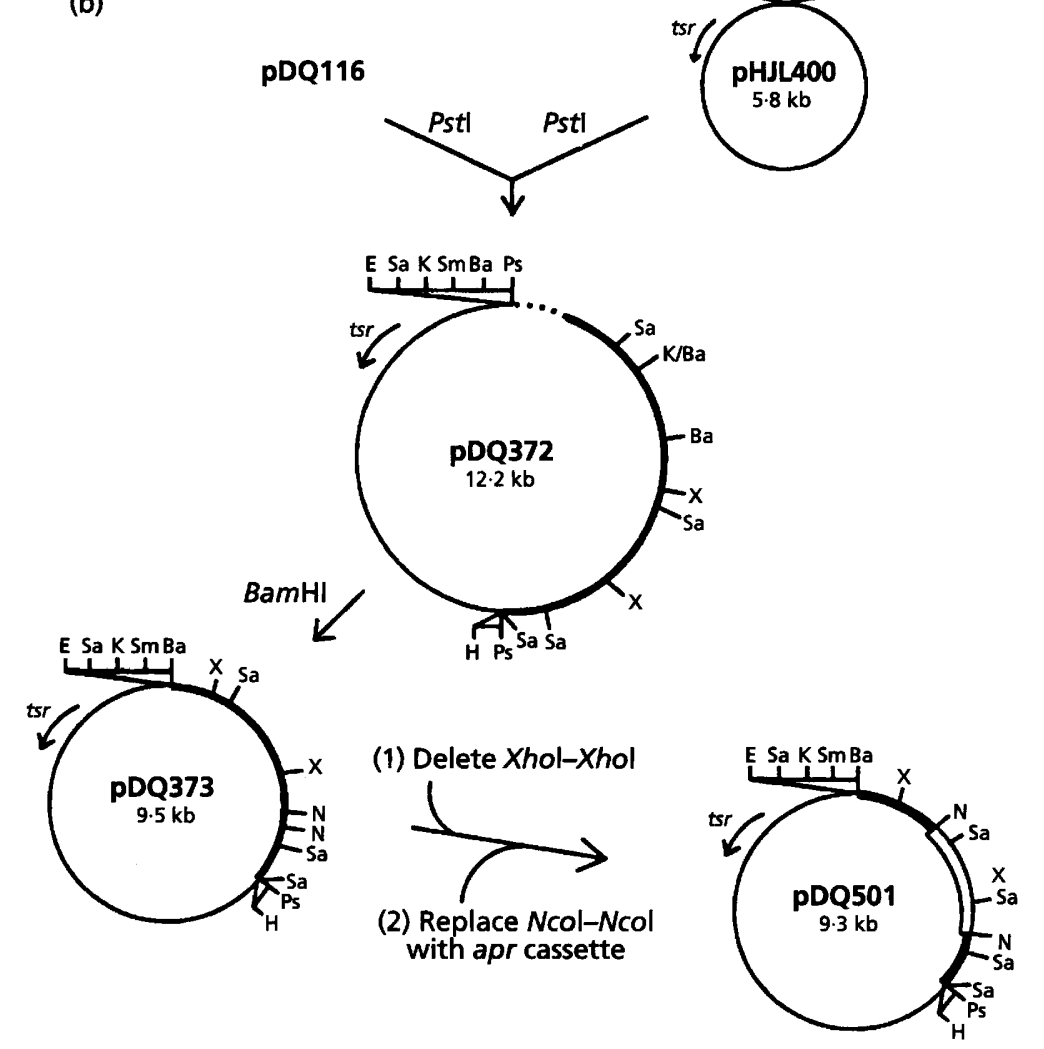

Fig. 2. (a) Restriction maps for $p D Q 116$ and pDQ121, and locations of ORF1 and pabAB. (b) Plasmids constructed during the cloning and disruption of $S$. venezuelae pabAB. Abbreviations: $\mathrm{Ba}, \mathrm{BamHI} ; \mathrm{Bg}, \mathrm{Bg} / \mathrm{ll} ; \mathrm{E}$, EcoRI; H, Hindlli; K, Kpnl; N, Ncol; Ps, Pstl; Pv, Pvull; Sa, Sacl; Sm, Smal; X, Xhol. bioassay against $M$. luteus). Seven of nine putative transformants of VS519 examined were sulfanilamideresistant; the other two retained the sensitivity (inhibition at $2 \mu \mathrm{g} \mathrm{ml}^{-1}$ ) of the host. All of the putative VS519 transformants showed by bioassay the pleiotropic, medium-dependent $\mathrm{Cm}$ production exhibited by the host. Since no plasmid DNA could be extracted from either VS519 or VS620 transformants, but a signal was detected in genomic DNA by Southern hybridization using the Ts resistance gene excised from the vector as a probe, integration was presumed to have occurred.

\section{Sequencing the pab gene in pDQ116}

To facilitate subcloning and disruption of the pabcomplementing DNA, the $6.4 \mathrm{~kb}$ Pst $\mathrm{I}-P_{s t} \mathrm{I}$ fragment from pDQ116 was recloned in the Streptomyces-E. coli shuttle vector pHJL400 (Larson \& Hershberger, 1986), yielding
pDQ371 and pDQ372 with the insert in each orientation. Both plasmids transformed S. lividans JG10 to sulfanilamide resistance. Digestion of pDQ372 (Fig. 2b) with $B a m \mathrm{HI}$ and ligation to recircularize the plasmid yielded pDQ373, in which the $3.0 \mathrm{~kb}$ segment between the Bam HI sites at $3.4 \mathrm{~kb}$ (in the insert) and $6.4 \mathrm{~kb}$ (in the multiple cloning region of the vector) had been deleted. PDQ373 failed to confer sulfanilamide resistance, as did pDQ374, in which digestion of $\mathrm{pDQ} 372$ with $X h o \mathrm{I}$ followed by ligation had deleted the $1.24 \mathrm{~kb}$ DNA segment between the two $X b o I$ sites. Therefore, the gene conferring sulfanilamide resistance was presumed to lie in the region between the $X b o I$ site at $1.3 \mathrm{~kb}$ and the end of the insert at $5.65 \mathrm{~kb}$ (see Fig. 2a). To locate the gene more precisely, the region between the $S a c \mathrm{I}$ site at $0.6 \mathrm{~kb}$ and the $\mathrm{BamHI}$ site at $3.4 \mathrm{~kb}$ was subcloned as smaller fragments in both orientations in the phagemid pBluescript II SK(+) and sequenced (Fig. 3). 
BamHI -..-on:1---,

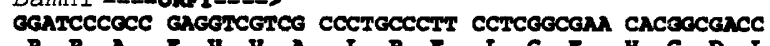

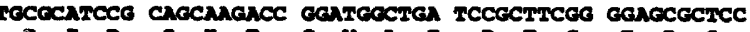
R I R S K I G M I I R F G E R S

101

151

51

201

251

301

101

351
118

101

134

451

151

501

551

601

1651

3

701

20

751
36

36

801

53

70

901

951

103

100

120

105

1101

153

115

120

203

1302

220

236

236

140
253

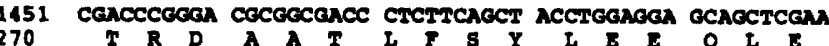

270 T $R$ R
1601 320

165 336

1701
353

175

370

1801

386

1851
403

1901

420

1951

436

2001

453

2051

470

2101

2151

503

2201

520

2251

536

2301
553

235

$\mathbf{5 7 0}$

2401

586

2451

603

2501
620

255

636

2601

\section{3}

2651

670

2701

2751

2801

Fig. 3. Nucleotide and deduced amino acid sequence of the BamHl-Sacl region of the S. venezuelae ISP5230 chromosome containing pabAB. A ribosome binding site (RBS, underlined) and the initiation codon (ATG, bold type) for ORF2 are indicated. Asterisks indicate termination codons (TGA).

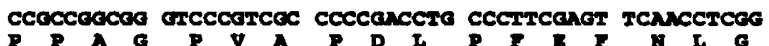
cracotceoc mactegect acenectem gocegaence accegcence

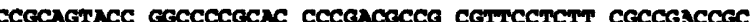

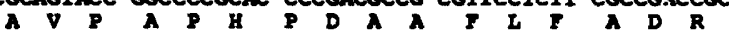

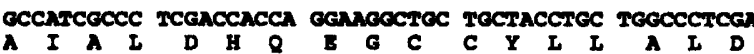

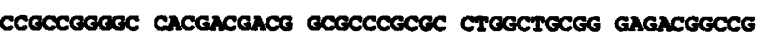
$\begin{array}{lllllllllllllllll}R & R & G & H & D & D & G & A & R & A & \text { H } & \text { I } & \mathbf{R} & \mathbf{Z} & \mathbf{T} & \boldsymbol{A} & \mathbf{E}\end{array}$

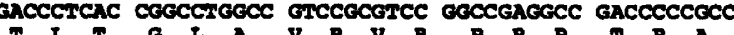

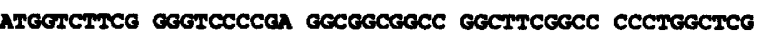

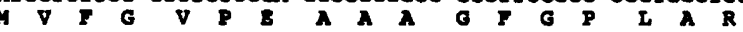
cocacgccac gacangeaco cCrcceccct ccecalcgec gagtcotace

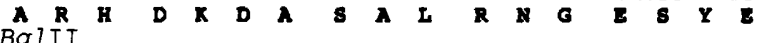

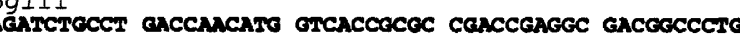

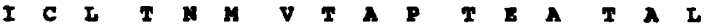

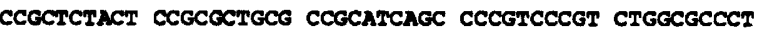

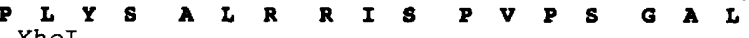
GCTCGAGTTC CCCGAGCTGT CGGTGCTCAG CGCCTCGCCC GAGCGGTTCC

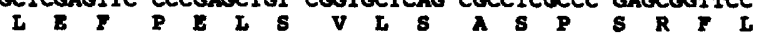

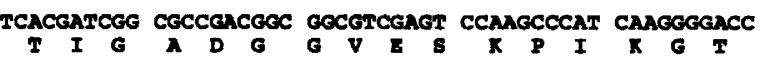

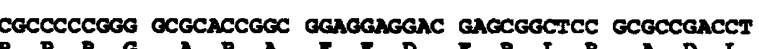
$\begin{array}{llllllllllllllllll} & \mathbf{P} & \mathbf{R} & \mathbf{G} & \mathbf{A} & \mathbf{P} & \mathbf{A} & \mathbf{B} & \mathbf{E} & \mathbf{D} & \mathbf{E} & \mathbf{R} & \mathbf{I} & \mathbf{R} & \mathbf{A} & \mathbf{D} & \text { L }\end{array}$

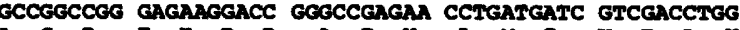

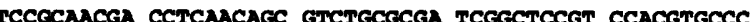
$R$ N D $L$ N S V C A I G S V H V P

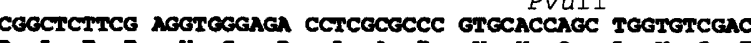
$\begin{array}{llllllllllllllll}L & F & B & V & G & D & I & A & P & V & H & Q & I & V & S & T\end{array}$

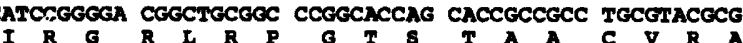
CCGCCTTCCC CGGCGGCTCC ATGACCGCCg CGCCCAAGAA gCGACCCATG

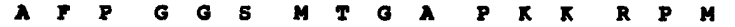

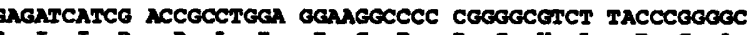

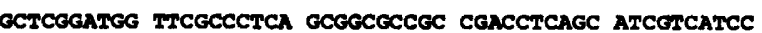
L $G$ W F A L 8 G A A $D$ I $S$ S I V I R

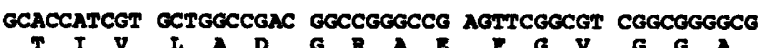

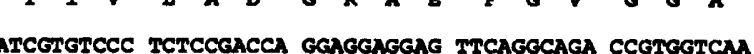
$\begin{array}{lllllllllllllll}I & V & 8 & L & 5 & D & Q & E & E & B & F & Q & T & V & \end{array}$

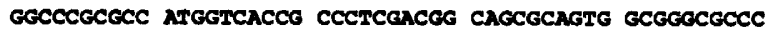

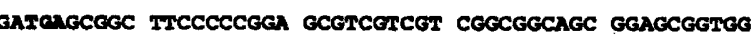
GCGCGCCATG THCGCGGGC TeCTGCGeGA GeCGGCCAGC CGCACGCTCe

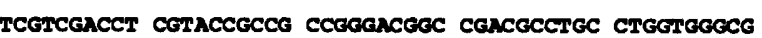
acotcaccec eccegegcec SacI

\section{Sequence analysis}

The overall $G+C$ content $(72 \cdot 4 \%)$ of the sequenced region is within the range reported $(61 \cdot 0-79 \cdot 7 \%)$ for streptomycete genes (Wright \& Bibb, 1992). Analysis of codon usage with the CODONPREFERENCE program (GCG) using the data of Wright \& Bibb (1992) for streptomycetes indicated two potential ORFs. One of these (ORF1) is incomplete and begins upstream of the $B a m \mathrm{HI}$ end of the cloned fragment. ORF2 begins 140 bp downstream of the 
(a)

120 SV MRTIIDYYD SFTOKLFOYI GEATGOPPVV PNDADWSRLP ..LEDFDAIV Sg MRTLLVDNYD SFTYNLFHYI SRANGREPEV IRNDDPAWRP GLLDAPDNVV Ka MILLIDNYD SFTWATYYOY CRT,GAEVLV RRNDELTLAD IISLAPAXIV St MIULIDKYD SFTWRZYOYF CEI.GAEVOV RRNDALTTAH IDAINPOXIV BC MILLIDNYD SFTWRLYOYF CEL.GADVLV KRNDALTLAD IDALKPOXIV Bs .MILMIDNYD SFTYNLVQYL GEL.GEELVV KRNDSITIDE IEELSPDFLM Ab .MLLLIDNYD SFTYYLVHYL GBL.GAELDV RRNDSLTVEE AMALRPEGIV 51 * ******* GEL. GAELDV RRNDSLTVEE AMALRPEGIV SV VSPGPGSPDR ERDFGISRRA ITDSGLPVLG VCLGHQGIAR L........SA Sg LSPGPGTPHR PADPGLCARI ARTGRLPVLG VCLGHOGMAL AHGARVGRAP RA ISPGPCTPDE SGISLAAIRH FS.GQTPILG VCLGHQAIAQ VFGAIVRAA TC ISPGPCTPDE AGISLDVIPH YA.GRIPILG VCLCHOAMAO AFGGEVTMA B8 ISPGPCSPDE AGISLEAIRH FA.GRIPIPG VCLGHOSIAO VFGGDVVRAE Ab LSPGPCDPDK AGICLPLIDA AAKAAVPLMG VCLGHQAIGQ PFGGTVVRAP 101

150 SV EPMHGRVSEV RHTGEDVFRG LPSPPTAVRY HSLAA..TDL PDELEPLAWS Sg EPRHGRTSAV RHDGTGLPEG LPQPLEVVRY HSLAV...TEI PPELEATAWS Xa KVMHGKTSPV SHTGOGVFLG LNNPLTVTRY HSLLIDPRTL PECFEVTARS St KVMHGKTSPV THWGQGVRR LPSPLTVTRY HSLIVDPATL PECFEITAWS BC KVMHGKTSPI THNGEGVPRG LANPLTVTRY HSLVVEPDSL PACPDVTAWS BE RIMHGKTSDI EHDGKTIFEG IXNPLVATRY HSLIVKPETL PSCPTVTAOT Ab VPMHGKVDRM FHQGRGVLO LPSPFRATRY HSLIVERATL PACLEVTGET

$$
\text { "* * * " **" * " * } 200
$$

SV DDGVVMGLRH REXPLMGVOF PPESIGSDFG REIMANFRDL ALAHHRARR. Sg EDGVLMALRH RTLPLWGVOF HPESIGTODG HRLLANFRDL TERHGRTRHG Ka EBGEIMGIRH RVFDLEGVOF HPESILSEOG HOLLANFLNR $\ldots \ldots \ldots$ St BTOEIMGIRH REWDLEGVOF HPESILSEDG HALLKNFLRR $\ldots \ldots \ldots$ RE ETRETMGIRH ROWDLEGVOF HPESILSEOG HOLTANYTHR $\ldots \ldots \ldots$ Bs KEGEIMAIRH NDLPIEGVQR HPESIMMSFG KENTRNFIET YRKEVIA... Ab BDGLIMALSH RELPIHGVQF HPESIESEHG HRILENFLN TRRLETAA. $201 \div 212$ Sv $\ldots \ldots \ldots . . . . . .$. Ta Grachoripr pa st $\ldots \ldots \ldots \cdots \cdots$ Ec Be

ab $\ldots \ldots \ldots$. (b)

SV Sg AGHGTLPPPA PARETRATTG TPRRLRVIAK SLPTRWDAEV AFDSLFRTGD K St $\ldots \ldots \ldots \ldots \ldots \ldots \ldots$. FAPVNHLP

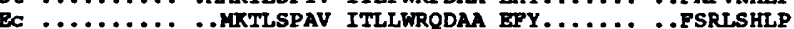
PP $\ldots \ldots \ldots \ldots$ NREEFLRLAA VGYNRIPLAC ETLADFDTPL SIYLXLADQP S1 ....MASCRM GARSALEPCQ VDCL...DEA ADE....... . .RCAETPRC

51

SV ATPWLDSSSV LEGASPFSPL GDDRGPLAEY LTYRVADGVV SVRGSDGTYT Sg HPFWLDSSRP GGELGOLSMM GDASGPLART ARADVHAGTV TVRADGASST Ka WAMLLHSGPA BHAHNRPDII VAQ..PRATL VTHGQLTTL. .REGETVSTS St WAMTLHSGDA IHPYMRFDIL VAD...PVTTI TTRAOETTV. .CTARTTTVT Ec WAMLLHSGYA DHPYSRPDTV VAB..PICTL TTFGKETVV. .SESEKRTTT PO NSYLLESVOG GEKWGRYSHI GIP..SRTVM RVHGYYHSTI HDGVEVESHD PP RSYLLESVQG GEKWGRYSHI GLP...SRTVM RVHGYHVSSIL HDGVEVESHD 101

150 SV RDAATLFSYL EEQLEPPAGP VAPDLPPEPN LGYVGYLGYE LK....... Sg VESA.FLTWL ENDLAGLRTE V.PELPFAPA LGWVGCLGYE LX........ Ra AADP..LTLV HQQLAHCNLO PQPHPHLPPL GGALGLFGYD .... LLRRRFE St LDDP..LHVL QTQLEALPFH PQPDPDLPFQ GGALGLFGYD ....LLGRRFE BC TDDP..LQVL QOVLDRADIR PTHNEDLPFO GGALGLFGYD ....LLGRRFE PP VEDP..LAFV ESFKDRYKVA DIPGLP.RFN GGLVGYFGYD CVRYVEKRLG SI DEDP..LKGI RSVFELGDLD PTNHEEIEFO GGALGRFAYD .... IARRLE 151

200 SV ETTGDPAVPA PHPDAAFLFA DRAIALDHOE GCCYLLALDR RGHDDGARAW Sg ECDGDAAHRS PDPDAVLVFA DRALVLDHRT RTTYLLALVE DDAEAEARAW Xa HLPARADADI ELPDMAVGIY DWALIVDHOR REVSLFSYD. ...DPOARLA St ILPDTAARDI ALPDMAIGLY DWALIVDHOK OVVSLISYY. $\cdots$ DADARYR Ec SLPETAEODI VLPDMAVGIY DWALIVDHOR HTVSLLSHN. ....DVVNARRA PP VSPNPDP... GVPDILLMVS DAVVVYDNLA GKNHAIVLV. ....DPAEEQA S1 AIRDLGDREL AGPDAGTALY DLILY.DHQD DVIWILVPN. ....EAGEQDP

201

250 SV LRETAETLTG LAVRVRPRPT PAMVPGVPEA AAGFGPLARA RHDKDA.... Sg LAAASATLDA VAGREPE... . ....PCPEA PVCTTGPVEL RHDRDGYLKL st WTTSO $\cdots \cdots \cdots$. BC WLESO ............ P PQEDFTLTS. $\ldots .$. DW.OS MMTREQYGEX PP PEOGOARLOG ULETLROPIT PRRGLDLSGP OAAEPER.RS SYTREDYENA

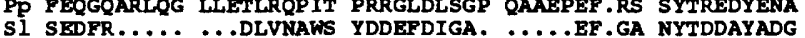
251

300 SV ..... SALRN GESYEICLTN MVTAPTEATA LPLYYSALRRI SPVPSGALLE Sg IDVCQQEIAA GETYEVCLTN MAEADTDLTP WAAYRALRRV SPAPFAAFLD Ka FRQIQAYLHS GDCYQVNLAQ RFTATYRGDE WQAFRQLNRA NRAPFSAPIR St FRQVQAWLHS GDCYQVNLSO RPQASYEGDE WQAFERLNRA WRAPFSAFLR BC PRQVQEYLHS GDCYQVNLAO RFHATYSGDE WQAPLOLNQA NRAPFSAFLR PP VGRIXEYILA GDCMQVVPSO RMSIDFKAAP IDLYRALRCF NPTPYMYFFN SI VDRLKDYLGS GDMYQVNLAQ RRVGMISAED YQLYIRLRDA NPAPYMAYLD

301

350

SV FPELSVLSAS PERPLTIGAD GGVESTPIXG T... RPRGAP AEEDERLRAD Sg FGPMAVLSSS PERFIRIDRH GRMESKPIXG T...RPRGAT POEDAALVRA Ka LDEGAVLSLS PERFIQLR. $Q$ GDIQTRPIXG TL....PRLAD PEQDALQQQR St LHDGAILSLS PERFIQLE.N GHIQTRPIKG TL...PRLLND PQADRQQAQK BC LEQGAILSLS PERTILCD.N SEIQTRPIKG TI....PRLPD PQEDSKQAVK PP PGDFHVVGSS PEVLVRVE.D NLVTVRPIAG T...RPRGAT EEADRALEDD S1 IDEG.LLVAS PERIILDE.A SDLDTRPIAG TLRGRPRAGG DDEDDGRAID 351

SV LAGREKDRAE MLMIVDLVRN DLNSVCAIGS VHVPRLFEVG DLAPVHOLVS Sg LATCEKDRAB RLMIVDLVRH DIGRCAEVGS VVADPVFOVE TYATVHQLVS Ra LANSPRDRAB NLMIVDLMRN DIGRVAEPGS VRVPELFVVE PFPAVHHLVS ST LANSMKDRAE NLMIVOLMRN DIGRVAVPGS VKVPELFVVE PFPAVHHLVS BC LANSAKDRAB NLMIVDIMRN DIGRUAYAGS VKVPELFVVE PFPAVHHLVS PP LLSDDREIAE HLMLIDLGRN DVGRVSSTGS VRLTEKMVIE RYSNVMHIVS SI LLRVDKDRAE RIMIVDLDRN DIARVGVGGS VKVREIMGLE RYSGVMMLVS 401

SV TIRGRLRPGT STAACVIAAF PGGSMTGAPX XRPMEIIDRL EEGPRGVIPG Sg TVTARLREDS SPVAAVRAAF PGGSMTGAPK IRTMQIIDRL EGGPRGVYSG Ka TVTARLPAHL HAADLLRAAF PGGSITGAPK VRAMEIIDEL EPORRNAWCG St TITARLPDSL HATDLLRAAF PGGSITGAPK VRAMEIIDEL EPQRRNAWCG EC TITAQLPEQL HASDLLRAAF PGGSITGAPR VRAMEIIDEL EPQRRNAWCG PP NVAGQLREGL TAMDALRAIL PAGTLSGAPR IRAMEI IDEL EPVKRGVYGG SI QVTGDLQEAI EAVDLIRAGP PGGTLTGAPK VRTMEIIDEL EPQRRAAYCG

451 SV ALGWPALSGA ADLSIVIRTI VLADGRABPG VGGATVSLSD QEEEFRQTVV Sg AIGYPSLTGA VDLSIVIRTV VISGGRLRYG VGGAVIALSD PADEPRETTAV KA SIGYLSFCGN MDSSITIRTL TAWOGKLYCS AGGGIVADSE EAAEYQETPD

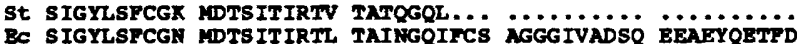
BC SIGYLSFCGN NDTSITIRTL TAINGQIFCS AGGGIVADSQ EEAEYQETPD PP AVGYFAWNGN MDTAIAIRTA VINDGELHVO AGGGIVADSV PALEWEETIN

501

Sv Taramytald gsavagar............

Sg TAAPLLRLLD TAFPGRERPG KDLDGEPDDG

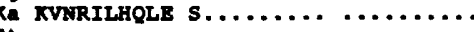

st $\ldots \ldots \ldots \ldots \ldots \ldots$

.................

PP RRPMAFRAVA LAERTSAK... indicate amino acids conserved in all sequences compared. 
(a)

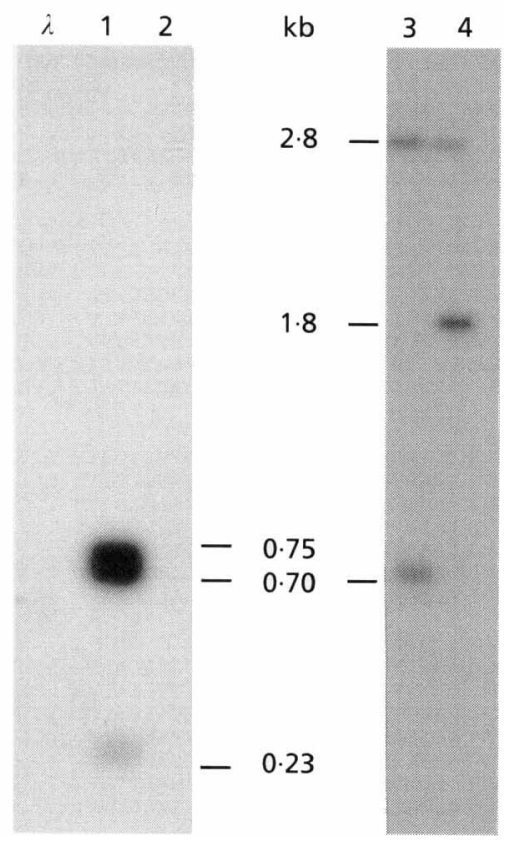

(b)
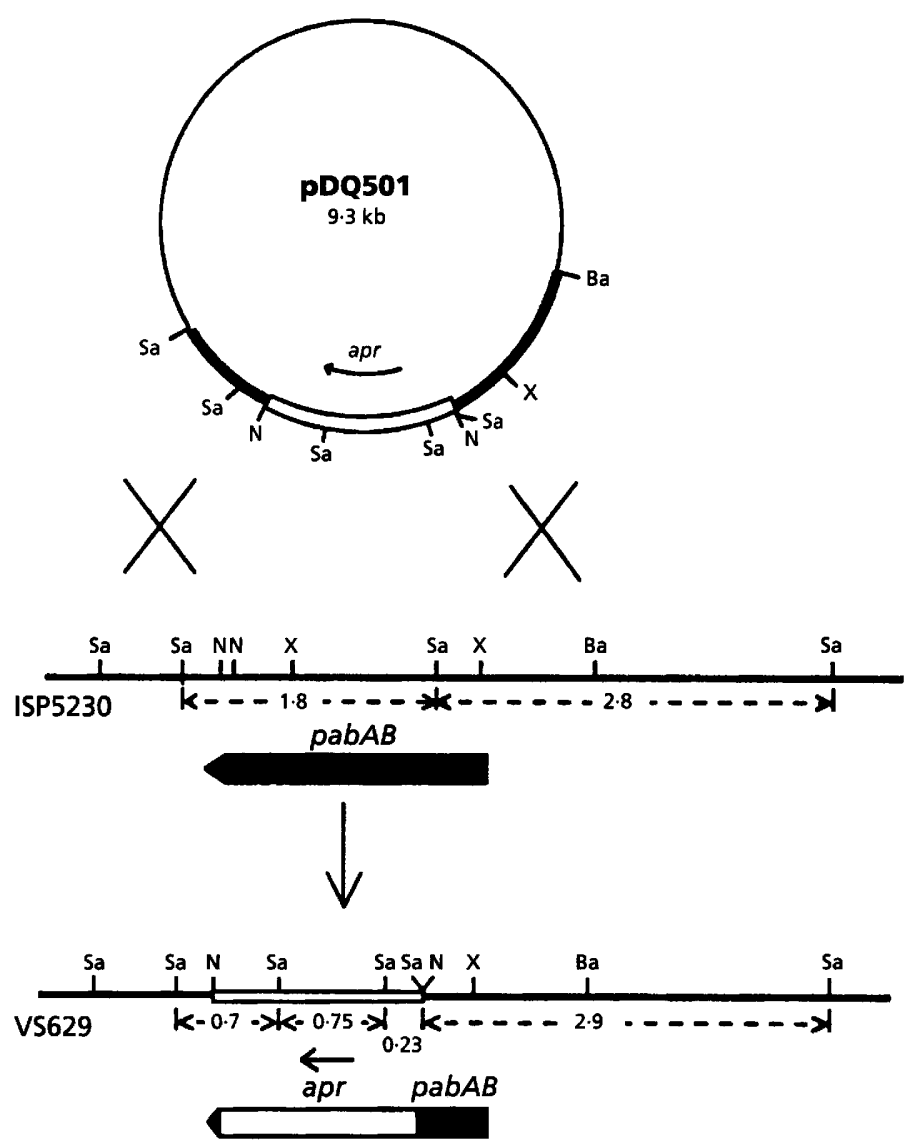

Fig. 5. (a) Southern hybridization of S. venezuelae genomic DNA from mutant (VS629; lanes 1 and 3 ) and wild-type (ISP5230; lanes 2 and 4) strains. The mutant contained the disruption vector pDQ501 integrated in its chromosome. Lane $\lambda$, $\lambda$ phage DNA digested with Pstl as size markers. Genomic DNA was digested with Sacl and probed with either a $1.45 \mathrm{~kb}$ Ncol-Ncol cassette containing apr (lanes $\lambda, 1$ and 2) or a $1.8 \mathrm{~kb}$ Sacl-Sacl fragment containing a segment of pabAB from pDQ373. (b) Restriction map showing the predicted result of a double crossover between homologous regions of DNA in PDQ501 and the S. venezuelae ISP5230 chromosome. The tips and shaded segment of the lower broad arrow represent regions in VS629 that hybridize with the pabAB probe. For abbreviations, see Fig. 2 legend.

TGA stop codon (nt 503-505) of ORF1 and contains 2010 bp. Its ATG start codon (nt 646-648) is preceded, with a 7 bp separation, by a putative ribosome binding site (GGTG; $\Delta G=-9 \cdot 4 \mathrm{kcal} \mathrm{mM}^{-1}$; Tinoco et al., 1973). The stop codon for ORF2 is at nt 2654-2656.

The amino acid sequences for ORFs 1 and 2 were compared with those in the GenBank database using the BLASTP program (Altschul et al., 1990). No meaningful similarities were found for the partial sequence of ORF1. However, the sequence of ORF2 showed marked similarity (47.5\% identical amino acids) to that deduced for the product of pab $A B$ from S. griseus (Criado et al., 1993). The sequence of about 200 amino acids nearest the $\mathrm{N}$ terminus of ORF2 from $S$. venequelae also resembled that of the $\operatorname{pab} A$ products from many bacteria, while the sequence of the approximately 450 amino acids remaining was similar to $p a b B$ product sequences. These relationships were confirmed by alignment (Fig. 4) of the two regions of the $p a b A B$ product with the corresponding $p a b$ gene products using the PILEUP program (GCG) based on the algorithm of Feng \& Doolittle (1987). The marked similarity between the pab $A B$ products of $S$. griseus and $S$. venezuelae was supported by a comparison of the sequences using the PLOTSIMILARITY program (GCG). In general, the areas of high similarity correspond to conserved regions in PabA and PabB (Crawford, 1989).

\section{Disruption of pabAB}

The potential involvement of $p a b A B$ in the biosynthesis of PABA and $\mathrm{Cm}$ was examined by disrupting the gene in $S$. venezuelae ISP5230. A disruption vector was prepared from $\mathrm{pDQ} 373$, which contained $p a b A B$ within a $3.4 \mathrm{~kb}$ fragment cloned between Bam $\mathrm{HI}$ and PstI in the multiple cloning region of the Streptomyces-E. coli bifunctional vector $\mathrm{pHJL} 400$; this vector is segregationally unstable in streptomycetes (Larson \& Hershberger, 1986). pDQ373 was modified by removing $1.4 \mathrm{~kb} X h o \mathrm{I}-X b o \mathrm{I}$ and $0.21 \mathrm{~kb}$ $N c o I-N c o$ I segments of DNA from within $p a b A B$ to give pDQ500. Introducing an $\mathrm{NcoI}$ cassette carrying apr into 
the unique $\mathrm{N} c o$ I site of the resulting plasmid furnished the disruption vector pDQ501 (see Fig. 2b). To avoid restriction in $S$. venequelae ISP5230 apparently due to enzymes recognizing methylated DNA (Han et al., 1994), the plasmid was isolated from E. coli ET12567, which lacks DNA methylating systems (MacNeil et al., 1992). Transformation of $S$. venezuelae ISP5230 with pDQ501 initially yielded $\mathrm{Am}^{\mathrm{R}} \mathrm{Ts}^{\mathrm{R}}$ colonies; when these were propagated without antibiotic selection, $A \mathrm{~m}^{\mathrm{R}} \mathrm{Ts}^{\mathrm{S}}$ strains (e.g. VS629) were obtained.

Hybridization of SacI-digested genomic DNA using apr as probe gave signals for $0.23,0.70$ and $0.75 \mathrm{~kb}$ fragments only in the DNA from VS629, confirming the presence of $a p r$ in this strain (Fig. 5a). Probing of similar digests with a $1.8 \mathrm{~kb}$ SacI fragment containing most of pab $A B$ showed hybridizing fragments of 1.8 and $2.8 \mathrm{~kb}$ in the wild-type DNA; in VS629 DNA, a $2.9 \mathrm{~kb}$ fragment was present, but the $1.8 \mathrm{~kb}$ fragment was replaced by one at $0.70 \mathrm{~kb}$ that coincided with the $0.70 \mathrm{~kb}$ fragment hybridizing to the apr probe. The results are consistent with interruption of the $1.8 \mathrm{~kb}$ chromosomal segment by insertion of apr and with the presence in the VS629 chromosome of the expected segments of $p a b A B$ DNA (see Fig. 5b). From restriction enzyme and Southern analyses of the replacement vector, it was determined that apr was oriented for transcription in the same direction as pabAB. When cultures of these strains and the wild-type were grown in media favouring $\mathrm{Cm}$ production (Doull et al., 1985), the antibiotic titres measured by HPLC in the $\mathrm{Am}^{\mathrm{R}} \mathrm{Ts}^{\mathrm{R}}$ transformants were similar to wild-type levels $(60-70 \mu \mathrm{g}$ $\mathrm{ml}^{-1}$ at $6 \mathrm{~d}$ ), whereas those in the $\mathrm{Am}^{\mathrm{R}} \mathrm{Ts}^{\mathrm{s}}$ replacement strains were below $2 \mu \mathrm{g} \mathrm{ml}^{-1}$. Assays of the sensitivity of the replacement strain to sulfanilamide showed that growth was inhibited at concentrations above $5 \mu \mathrm{g} \mathrm{ml}^{-1}$.

\section{DISCUSSION}

Since the inhibition of some streptomycetes by sulfonamides can be reversed by adding PABA to the culture medium (Gil \& Hopwood, 1983), the approximately 10fold greater resistance of $S$. venezuelae than $S$. lividans to sulfanilamide could be explained by a higher endogenous level of PABA synthesis in S. venezuelae. This might be associated with the formation of 4-amino-4deoxychorismic acid as a common intermediate in the biosynthesis of PABA and $\mathrm{Cm}$. Considerably more 4amino-4-deoxychorismic acid must be generated to meet the needs of the secondary metabolic process than is required for the synthesis of folic acid cofactors in primary metabolism. An increased supply of the intermediate could be achieved by regulating the activity of a single $\mathrm{PABA}$ synthase, or by using a second enzyme supplying 4-amino-4-deoxychorismic acid in the amounts needed for $\mathrm{Cm}$ biosynthesis. The results obtained in the present investigation indicate that two types of PABA synthase exist in $S$. venequelae and thus support the second possibility.

Because the mutations causing sensitivity to sulfanilamide in VS519 and VS620 did not prevent $\mathrm{Cm}$ production, whereas replacing the chromosomal copy of the cloned pab $A B$ with a disrupted copy virtually eliminated synthesis of the antibiotic without causing auxotrophy, the genes associated with sulfanilamide sensitivity are likely to be involved in folic acid biosynthesis. PABA synthesis can potentially be affected by mutations in $p a b A, p a b B$ or $p a b C$ of this pathway; phenotypic differences between such mutants might account for the apparent differences in $\mathrm{Cm}$ production detected in bioassays, but these might also be due to additional mutations introduced by mutagenesis with NTG (Baltz, 1986). The restoration of sulfanilamide resistance as well as normal bioassay titres for $\mathrm{Cm}$ production when VS620 was transformed with pDQ102, which contains pab $A B$, supports the assumption that 4-amino-4-deoxychorismic acid generated in the $\mathrm{Cm}$ biosynthetic pathway can supply a similar need in the folic acid pathway. The failure of VS519 to respond similarly to transformation with $\mathrm{pDQ} 102$ may again be due to additional mutations introduced by mutagenesis with NTG.

The rapid integration of plasmids noted earlier (Aidoo $e t$ al., 1990) in S. venequelae transformed with recombinant vectors containing inserts of homologous DNA facilitated replacement of the chromosomal $p a b A B$ with a disrupted copy containing a gene for Am resistance. The increased sensitivity of the replacement mutant to sulfanilamide, in addition to its almost complete loss of $\mathrm{Cm}$ production, are consistent with the postulated linkage between sulfanilamide resistance and $\mathrm{Cm}$ production in $S$. venezuelae. The small amount of the antibiotic still made in the replacement strain can be attributed to crossfeeding of the $\mathrm{Cm}$ biosynthesis pathway by 4-amino-4deoxychorismic acid made by the intact primary PABA synthase.

The striking similarity between the $p a b A B$ genes from $S$. griseus and $S$. venezuelae lies not only in the deduced amino acid sequences but also in features of gene organization. In most bacteria, the glutamine amidotransferase component ( $p a b A$ product) of PABA synthase is about 190 amino acids in length and the average aminase $(p a b B$ product) contains about 450 amino acids. Thus the combined length of PABA synthase (about 640 amino acids) is somewhat smaller than the 670 amino acids estimated for the pab $A B$ product of $S$. venezuelae. In $S$. griseus, $p a b A B$ is even longer and encodes 723 amino acids. Sequence alignment of $p a b B$ proteins from bacteria indicates that much of the additional length of this component in $p a b A B s$ (about 10 unpaired amino acids in the $S$. venezuelae product and 30 in the $S$. griseus product) is at the $\mathrm{C}$-terminal end. In both pabABs, the component genes are fused in the same order, with the $p a b A$ component transcribed first. In $S$. lividans and $B$. subtilis, where $p a b A$ and $p a b B$ are separate but translationally coupled (Slock et al., 1990; Arhin \& Vining, 1993), pabB precedes pab $A$, and is itself preceded by a promoter sequence that is recognized in $E$. coli. In contrast, the indigenous promoter for $p a b A B$ in $S$. venezuelae, although expressed in streptomycetes (e.g. in pDQ116 transformants of $S$. lividans JG10), is not recognized in E. coli. A similar situation was reported for $p a b A B$ of $S$. griseus; here the gene was expressed in E. coli only after a deletion 
allowed read-through from a vector promoter (Gil \& Hopwood, 1983; Criado et al., 1993).

Although pDQ 373 contains an intact ORF2 for $p a b A B$ of $S$. venezuelae, it was unable to confer sulfanilamide resistance in transformants of $S$. lividans JG10. This and the absence of recognizable promoter sequences for ORF2 suggest that transcription does not begin immediately upstream of $p a b A B$. Instead, the promoter site may be associated with an upstream region cotranscribed with $p a b A B$. This appears to include ORF1, the identity of which could not be established by comparing the deduced partial sequence with proteins in the GenBank database. In $S$. griseus the native $\operatorname{pab} A B$ promoter was placed between 0.2 and $1.2 \mathrm{~kb}$ upstream of the gene (Gil \& Hopwood, 1983) in a region containing a putative thioesterase gene that may form part of a candicidin biosynthesis gene cluster (Criado et al., 1993). It is noteworthy that pDQ121, with the same pabAB-containing $S$. venezuelae $\mathrm{DNA}$ insert as $\mathrm{pDQ} 373$, conferred sulfanilamide resistance in S. lividans JG10 transformants. Presumably the gene is expressed here by read-through from a streptomycete promoter in the vector (pIJ41).

The presence in two different streptomycetes of secondary metabolic pathway genes very similar in organization and function and also similar enough to related primaty metabolic genes to indicate a common ancestry raises intriguing questions about the origin of secondary metabolic pathway genes. In both $S$. griseus and $S$. venezuelae, pab $A B$ encodes an enzyme that acts near the beginning of unique biosynthetic sequences. If the pathways to $\mathrm{Cm}$ and candicidin have arisen by forward rather than retrograde metabolic evolution, the distinctiveness and complexity of these two specialized biosynthetic systems suggest that $p a b A B$ has existed for a relatively long time. This being so, secondary metabolism itself is likely to have been an ancient process.

\section{ACKNOWLEDGEMENTS}

We are grateful to Dr J. Gil, Oviedo University, for the culture of S. lividans JG10, to Dr A.S. Paradkar, University of Alberta, for the NcoI cassette containing the apramycin resistance gene and to Dr C.L. Hershberger, Eli Lilly \& Company, for the vector pHJL400. This work was supported by the Natural Sciences and Engineering Research Council of Canada.

\section{REFERENCES}

Aidoo, D. A. (1989). Approaches to the cloning of genes for chloramphenicol biosynthesis in Streptomyces venezuelae ISP5230. PhD thesis, Dalhousie University, Halifax, NS, Canada.

Aidoo, D. A., Barrett, K. \& Vining, L. C. (1990). Plasmid transformation of Streptomyces venezuelae: modified procedures used to introduce the genes for $p$-aminobenzoate synthetase. J Gen Microbiol 136, 657-662.

Altschul, S. F., Gish, W., Miller, W., Myers, E. W. \& Lipman, D. J. (1990). Basic local alignment search tool. J Mol Biol 215, 403-410.

Arhin, F. F. \& Vining, L. C. (1993). Organization of the genes encoding $p$-aminobenzoic acid synthetase from Streptomyces lividans 1326. Gene 126, 129-133.

Atkinson, L. (1987). A search for mutants of Streptomyces venequelae blocked in the synthesis of aromatic compounds due to mutations in glutamine amidotransferase genes. MSc thesis, Dalhousie University, Halifax, NS, Canada.

Baltz, R. H. (1986). Mutagenesis in Streptomyces spp. In Manual of Industrial Microbiology and Biotechnology, pp. 184-190. Edited by A. L. Demain \& N. A. Solomon. Washington, DC: American Society for Microbiology.

Carter, P., Bedovelle, H. \& Winter, G. (1985). Improved oligonucleotide site-directed mutagenesis using M13 vectors. Nucleic Acids Res 13, 4431-4443.

Chater, K. F., Hopwood, D. A., Kieser, T. \& Thompson, C. J. (1982). Gene cloning in Streptomyces. Curr Top Microbiol Immunol 96, 69-95.

Chatterjee, S., Vining, L. C. \& Westlake, D. W. S. (1983). Nutritional requirements for chloramphenicol biosynthesis by Streptomyces venezuelae. Can J Microbiol 29, 247-253.

Crawford, I. P. (1989). Evolution of a biosynthetic pathway: the tryptophan paradigm. Annu Rev Microbiol 43, 567-600.

Criado, L. M., Martin, J. F. \& Gil, J. A. (1993). Nucleotide sequence of the $p$-aminobenzoic acid synthetase gene of Streptomyces griseus IMRU 3570. Gene 126, 123-128.

Delic, V., Hopwood, D. A. \& Friend, E. J. (1970). Mutagenesis by $N$-methyl- $N^{\prime}$-nitro- $N$-nitrosoguanidine. Mutation Res 9, 167-182.

Denhardt, D. T. (1966). A membrane filter technique for the detection of complementary DNA. Biochem Biopbys Res Commun 23, 641-646.

Doull, J., Ahmed, Z., Stuttard, C. \& Vining, L. C. (1985). Isolation and characterization of Streptomyces venequelae mutants blocked in chloramphenicol biosynthesis. J Gen Microbiol 131, 97-104.

Feng, R. \& Doolittle, R. F. (1987). Progressive sequence alignment as a prerequisite to correct phylogenetic trees. $J$ Mol Evol 25, $351-360$.

Gil, J. A. \& Hopwood, D. A. (1983). Cloning and expression of a $p$ aminobenzoic acid synthetase gene of the candicidin-producing Streptomyces griseus. Gene 25, 119-132.

Gil, J. A., Liras, P., Naharro, G., Villanueva, J. R. \& Martin, J. F. (1980). Regulation by aromatic amino acids of the biosynthesis of candicidin by Streptomyces griseus. J Gen Microbiol 118, 189-195.

Goncharoff, P. \& Nichols, B. P. (1988). Evolution of aminobenzoate synthetases: nucleotide sequences of Salmonella typhimurium and Klebsiella aerogenes pabB. Mol Biol Evol 5, 531-538.

Green, J. M. \& Nichols, B. P. (1991). $p$-Aminobenzoate biosynthesis in Eschericbia coli: purification of aminodeoxychorismate lyase and cloning of pabC. J Biol Chem 266, 12971-12975.

Green, J. M., Merkel, W. K. \& Nichols, B.P. (1992). Characterization and sequence of Escherichia coli pabC, the gene encoding aminodeoxychorismate lyase, a pyridoxal phosphate-containing enzyme. J Bacteriol 174, 5317--5323.

Han, L., Yang, K., Ramalingam, E., Mosher, R. H. \& Vining, L. C. (1994). Cloning and characterization of polyketide synthase genes for jadomycin B biosynthesis in Streptomyces venequelae ISP5230. Microbiology 140, 3379-3389.

Hanahan, D. (1983). Studies on transformation of Escherichia coli with plasmids. $J$ Mol Biol 166, 557-580.

Henikoff, S. (1984). Unidirectional deletion with exonuclease III creates targeted breakpoints for DNA sequencing. Gene 28, 351-359.

Holmes, D. S. \& Quigley, M. (1981). A rapid boiling method for the preparation of bacterial plasmids. Anal Biochem 114, 193-200.

Hopwood, D. A. (1967). Genetic analysis and genome structure in Streptomyces coelicolor. Bacteriol Rev 31, 373-403. 
Hopwood, D. A., Bibb, M. J., Chater, K. F., Kieser, T., Bruton, C. J., Kieser, H. M., Lydiate, C. P., Smith, C. P., Ward, J. M. \& Schrempf, H. (1985). Genetic Manipulation of Streptomyces. A Laboratory Manual. Norwich: John Innes Foundation.

Huang, L. H. \& Pittard, J. (1967). Genetic analysis of mutant strains of Escherichia coli requiring $p$-aminobenzoic acid for growth. $J$ Bacteriol 102, 767-773.

Jones, A., Francis, M. M., Vining, L. C. \& Westlake, D. W. S. (1978). Biosynthesis of chloramphenicol in Streptomyces sp. 3022a. Properties of an aminotransferase accepting $p$-aminophenylalanine as a substrate. Can J Microbiol 24, 238-244.

Kaplan, J. B., Merkel, W. K. \& Nichols B. P. (1985). Evolution of amidotransferase genes: nucleotide sequences of the $p a b A$ genes from Salmonella typhimurium, Klebsiella aerogenes and Serratia marcescens. J Mol Biol 183, 451-462.

Karger, B. D. \& Jessee, J. (1990). Preparation of single-strand DNA from phagemids. Focus 12, 28-29.

Kieser, T. (1984). Factors affecting the isolation of cccDNA from Streptomyces lividans and Escherichia coli. Plasmid 12, 19-36.

Larson, J. L. \& Hershberger, C. L. (1986). The minimal replicon of a streptomycete plasmid produces an ultrahigh level of plasmid DNA. Plasmid 15, 199-209.

Liao, X., Vining, L. C. \& Doull, J. L. (1995). Physiological control of trophophase-idiophase separation in streptomycete cultures producing secondary metabolites. Can J Microbiol 41, 309-315.

Lingens, F. \& Keller, E. (1983). Zur Biosynthese von Phenylalanin und Tyrosin. Arogensäure, ein neues Zwischenprodukt. Naturwissenschaften 70, 115-118.

MacNeil, D. J., Gewain, K. M., Rudy, C. L., Dezeny, G., Gibbons, P. H. \& MacNeil, T. (1992). Analysis of Streptomyces avermitilis genes required for avermectin biosynthesis utilizing a novel integration vector. Gene 111, 61-68.

Malik, V. S. \& Vining, L. C. (1970). Metabolism of chloramphenicol by the producing organism. Can J Microbiol 16, 173-179.

Mead, D. A. \& Kemper, B. (1988). Chimeric single-stranded DNA phage-plasmid cloning vectors. In Vectors, pp. 85-102. Edited by R. L. Rodriguez \& D. T. Denhardt. Toronto: Butterworth.

Nichols, B. P., Seibard, A. M. \& Doktor, S. Z. (1989). paraAminobenzoate biosynthesis from chorismate occurs in two steps. $J$ Biol Chem 264, 8597-8601.

Paradkar, A. S. \& Jensen, S. E. (1995). Functional analysis of the gene encoding the clavaminate synthase 2 isoenzyme involved in clavulanic acid biosynthesis in Streptomyces clavuligerus. J Bacteriol 177, 1307-1314.

Sambrook, J., Fritsch, E. F. \& Maniatis, T. (1989). Molecular Cloning: A Laboratory Manual. Cold Spring Harbor, NY: Cold Spring Harbor Laboratory.

Sanger, F., Nicklen, S. \& Coulson, A. R. (1977). DNA sequencing with chain-terminating inhibitors. Proc Natl Acad Sci USA 74, 5463-5467.

Slock, J., Stahly, D. P., Han, C.-Y., Six, E. W. \& Crawford, I. P. (1990). An apparent folic acid biosynthesis Bacillus subtilis folic acid biosynthetic operon containing $p a b$, an amphibolic $\operatorname{tr} p G$ gene, a third gene required for synthesis of para-aminobenzoic acid and the dihydropteroate synthetase gene. J Bacteriol 172, 7211-7226.

Southern, E. M. (1975). Detection of specific sequences among DNA fragments separated by gel electrophoresis. J Mol Biol 98, 503-517.

Stanzak, R., Matsushima, P., Baltz, R. H. \& Rao, R. N. (1986). Cloning and expression in Streptomyces lividans of clustered erythromycin biosynthesis genes from Streptomyces erythreus. Bio/Technology 4, 229-232.

Stuttard, C. (1982). Temperate phages of Streptomyces venezuelae: lysogeny and host specificity shown by SV1 and SV2. J Gen Microbiol 128, 115-121.

Teng, C. Y., Ganem, B., Doktor, S., Nichols, B. P., Bhatnagar, R. K. \& Vining, L. C. (1985). Total biosynthesis of 4-amino-4deoxychorismic acid: a key intermediate in the biosynthesis of $p$ aminobenzoic acid and L- $p$-aminophenylalanine. $J A m$ Chem Soc 107, 5008-5009.

Tinoco, I., Jr., Borer, P. N., Dengler, B., Levine, M. D., Uhlenbeck, O. C., Crothers, D. M. \& Gralla, J. (1973). Improved estimation of secondary structure in ribonucleic acids. Nature New Biol 246, 40-41.

Tran, P. V., Bannor, T. A., Doktor, S. Z. \& Nichols, B. P. (1990). Chromosomal organization and expression of Escherichia coli pab $A$. $J$ Bacteriol 172, 397-410.

Vining, L. C. \& Stuttard, C. (1994). Chloramphenicol. In Genetics and Biochemistry of Antibiotic Production, pp. 505-530. Edited by L. C. Vining \& C. Stuttard. Boston: Butterworth-Heinemann.

Wright, F. \& Bibb, M. J. (1992). Codon usage in the $\mathrm{G}+\mathrm{C}$-rich Streptomyces genome. Gene 113, 55-65.

Received 2 October 1995; revised 18 January 1996; accepted 22 January 1996. 